\title{
Porophyllum pygmaeum (Asteraceae), a Distinctive New Species from Southern Nevada
}

\author{
DAVID J. KeIL \\ Biological Sciences Department, California Polytechnic State University, \\ San Luis Obispo, California 93407
}

JAMES D. MOREFIELD

Rancho Santa Ana Botanic Garden, 1500 N. College Avenue, Claremont, California 91711-3101

\begin{abstract}
Porophyllum pygmaeum is a new species from coarse calcareous soils of the Desert National Wildlife Range in Clark Co., Nevada. It has subterete leaves that contain a continuous double layer of palisade mesophyll surrounding a central area of larger, achlorophyllous, polyhedral parenchyma cells and veins. The hollow foliar oil glands lie just below the abaxial epidermis and are deeply invaginated within the parenchyma layers. Porophyllum pygmaeum is a tetraploid $(n=$ 24) perennial herb that apparently is most closely related to $P$. greggii, a hexaploid herbaceous species of western Texas with much longer and narrower leaves. In its fleshy subterete leaves $P$. pygmaeum resembles the subshrubby $P$. tridentatum of Baja California from which it differs by its chromosome number ( $n=15$ in $P$. tridentatum), by its dwarf herbaceous habit, by leaves that are always entire and that bear several pairs of submarginal glands, and by much longer achenes. The new species apparently is not closely related to P. gracile, the only other species of Porophyllum that occurs in southern Nevada and adjacent regions of Arizona and California.
\end{abstract}

Discovery of a single specimen of an unknown Porophyllum in the RSA herbarium prompted the second author to search for living plants in the field in May and June of 1987. On his second attempt, a day-long search paid off, and a single population was discovered in a remote unnamed valley in Clark Co., Nevada. Our study of specimens collected there confirms that these plants represent an undescribed species.

Porophyllum pygmaeum Keil \& Morefield, sp. nov. (fig. 1).-TYPE: U.S.A., Nevada, Clark Co., Desert National Wildlife Range, just W of Alamo Rd. between road and main drainage of the unnamed valley between $\mathrm{S}$ end of the Desert Range and the Sheep Range, 1.4 road mi [2.3 km] N of Hidden Forest Rd. turnoff, 12.2 air $\mathrm{km} \mathrm{N}, 46^{\circ} \mathrm{W}$ of Sheep Peak summit, ca. 56 air km NNW of Las Vegas, T15S R59E, NW 1/4 of SW $1 / 4$ of Sect. 9 (projected), $1355 \mathrm{~m}$, 4 Jun 1987, J. D. Morefield 4511 \& F. Ehrendorfer (holotype: RSA; isotypes: ARIZ, ASC, ASU, BRY, F, GH, K, MEXU, MO, NSMC, NY, OBI, POM, TEX, UC, UNLV, US, WU).-PARATYPES: U.S.A., Nevada, Clark Co., Desert National Wildlife Range, E bajada E of Target bench mark, Desert Range, $4600 \mathrm{ft}$ [1402 m], 16 May 1979, T. L. Ackerman 30906 (RSA, UC); third ridge $S$ of Deadman Canyon, Sheep Range, $6800 \mathrm{ft}$ [2073 m], $5 \mathrm{Jul} 1979, T$. L. Ackerman 30904 (UC); type locality, 22 Apr 1988 (in bud only; $2 n=24_{\text {II }}$ ), D. Keil 20459 (OBI, RSA); just W of Alamo Rd. between road and main drainage of the unnamed valley between $S$ end of the Desert Range and the Sheep Range, 2.5 road $\mathrm{mi}$ [4.0 km] N of Hidden Forest Rd. turnoff, 22 Apr 1988 (in bud only; $2 n=24_{\text {II }}$ ), D. Keil 20469 (OBI, RSA).

Porophyllum pygmaeum habitu herbaceo, formis magnitudibusque flosculorum, fructium et bractiorum involucri, et numero basico chromosomatum $(x=12)$ P. greggii A. Gray simulat, autem foliis crassioribus et multo brevioribus (10-15 mm adversus $20-80 \mathrm{~mm}$ ) cum 3-5 paribus glandium submarginalium contra glandiis numerosis differt. Foliis crassis subteretibus $P$. tridentatum Benth. var. tridentatum et var. crassifolium (S. Watson) I. M. Johnston simulat, autem habitu herbaceo nano, foliis cum 3-5 paribus glandium submarginalium et acheniis multo longioribus (7-8 $\mathrm{mm}$ longis contra 2.5$3.5 \mathrm{~mm})$, chromosomatum numero $(n=24$ ad- 


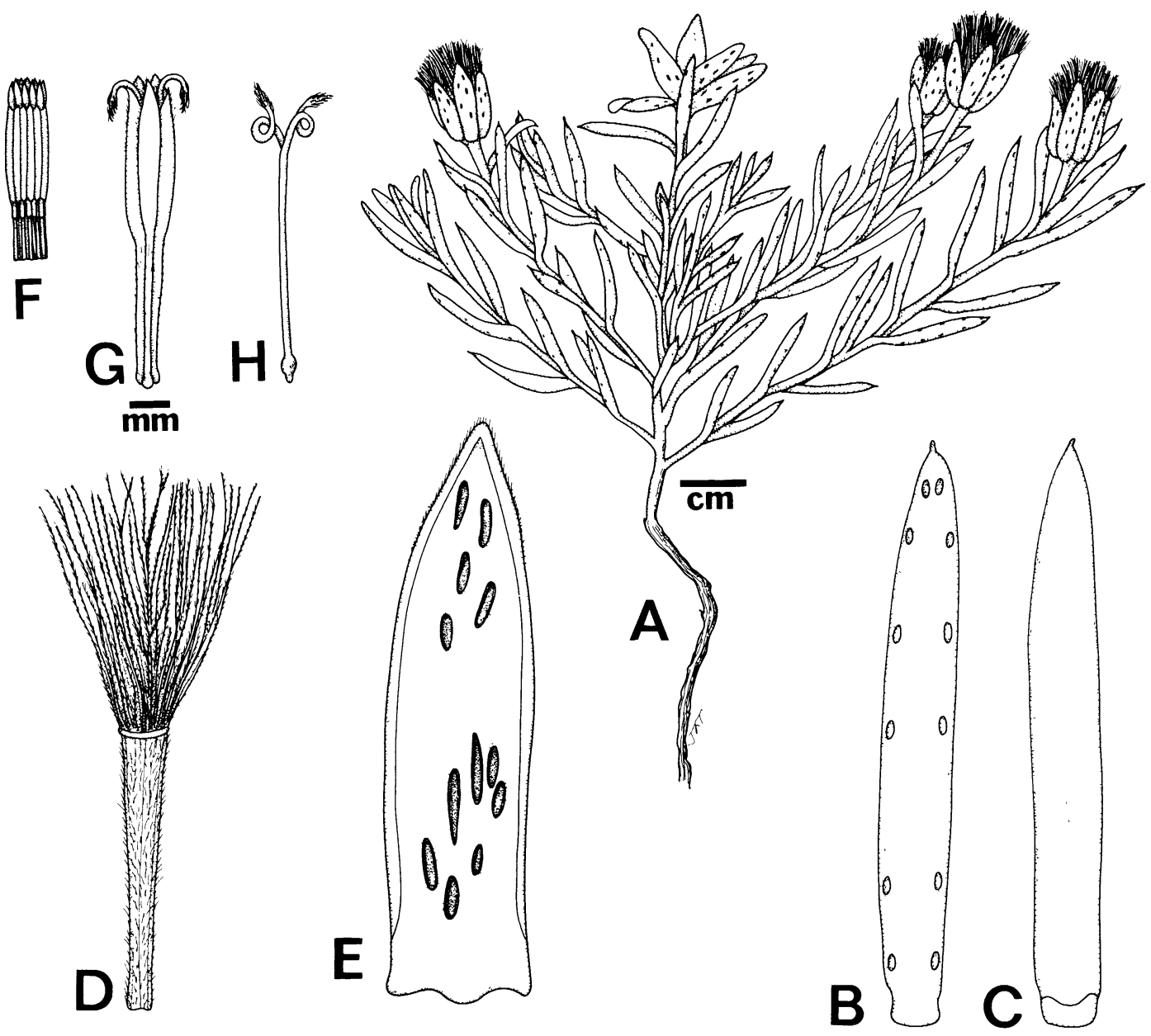

FIG. 1. Porophyllum pygmaeum. Drawn from Morefield 4511. A. Habit. B. Leaf (abaxial surface). C. Leaf (adaxial surface). D. Achene with pappus. E. Phyllary. F. Anthers. G. Corolla. H. Style. B-H drawn to same scale.

versus $n=15$ ), et a var. tridentata foliis semper integris differt.

Perennial herb from a slender woody rootstock to more than $15 \mathrm{~cm}$ long and $6 \mathrm{~mm}$ in diam.; herbage strongly scented. Stems 1-many, 5-15 cm tall, simple or few-branched, very leafy, purplish near the soil surface, green above, \pm striate, glabrous. Leaves subterete with an adaxial groove, $10-15 \mathrm{~mm}$ long, ca. $2 \mathrm{~mm}$ in diam., reduced and scalelike at stem base, not much-reduced below heads, entire, 3-nerved but the veins and veinlets visible only in cleared or sectioned leaves; apex mucronate; surface glabrous, punctate with a pair of subterminal pellucid oil glands and 3-5 pairs of ellipsoid to spherical submarginal glands $0.3-0.7 \mathrm{~mm}$ in diam., the glands becoming rusty brown upon drying. Heads solitary, terminal; peduncle stout, fistulose, 5-15 mm long. Involucre cylindrical at anthesis to campanulate in age or when pressed; phyllaries 5-8, oblong, 8-11 $\mathrm{mm}$ long, 2-4 mm wide, persistent and spreading to reflexed in age, the apex obtuse to subacute, minutely erose-ciliolate, the margin narrowly hyaline/scarious, the abaxial surface broadly rounded, dotted with several to many oblong pellucid oil glands $0.5-1.5 \mathrm{~mm}$ long. Florets 2575; corollas 7-8 $\mathrm{mm}$ long, pale yellow, often greenish or reddish tinged, the veins darker, the tube 4-4.5 $\mathrm{mm}$ long, the throat $2.5-5 \mathrm{~mm}$ long, the lobes short-triangular, $0.5 \mathrm{~mm}$ long, sometimes reddish; anthers $\pm 3 \mathrm{~mm}$ long; pol- 
len bright yellow, 28-36 $\mu \mathrm{m}$ in diam.; style included or slightly exserted, the terminal appendages narrowly conical, acute, coiled in age. Achenes narrowly cylindrical, 7-8 mm long, black, hirtellous with ascending bicellular trichomes 0.1-0.2 mm long; pappus bristles 5060 , tawny, barbellate, unequal in length and diameter, up to 6 or $7 \mathrm{~mm}$ long. $n=24$.

Distribution, Habitat, and Phenology. Porophyllum pygmaeum is known only from the southern portion of the broad dry valley between the Desert Range and the Sheep Range in the Desert National Wildlife Range, Clark County, Nevada. At the type locality and the site of Keil 20459 (1.1 miles N of the type locality) the species occurs on an open alluvium derived from the almost exclusively carbonate rock of the adjacent west-draining slope of the Sheep Range. A surface layer of pebble- to cobblesized fragments is underlain by rocky soil with clay, silt, and sand particles. Rock samples collected from the soil surface at the type locality were determined as dolomite and calcitic dolomite, some of which had recrystallized as marble. Soil $\mathrm{pH}$ at the type locality is approximately 8.0 [determined with a Hellige-Truog soil reaction $(\mathrm{pH})$ tester no. 693]. We have not yet had the opportunity to visit the locality of Ackerman 30904.

Porophyllum pygmaeum grows in colonies (perhaps clones connected by underground rootstocks), most of which occupy either shallow $(<15 \mathrm{~cm})$ depressions in the alluvium, or banks and benches adjacent to the shallow $(<50 \mathrm{~cm})$ drainages. They occur in open areas rather than in places shaded by larger plants.

Plants of P. pygmaeum are inconspicuous and easily overlooked, even at close range, except when they are in flower. On casual inspection their vegetative features resemble those of other local herbaceous perennials. The stems die back well below the soil surface during dormancy. Though local rainfall amounts for 1987 are not known, the area appeared to have received spring rainfall far in excess of average. Annuals of large stature were still in profuse bloom at the beginning of June, and the soil was palpably moist to at least $40 \mathrm{~cm}$ depth. We consider it likely that in normal or dry years, fewer or smaller individuals of $P$. pygmaeum would be in evidence at the type locality than were found in 1987.

At the type locality P. pygmaeum is frequent over an area of at least 0.2 square $\mathrm{km}$. The site represented by Keil 20469 may be a continuation of the same population. These populations are directly downgrade from the population represented by Ackerman 30904. The extent of the latter population is unknown at present. Because of insufficient label data, we have been unable to determine whether the type locality and the collection site for Ackerman 30906 are the same; if they are not, we are confident that they are close.

Based upon our observations of the known localities of $P$. pygmaeum, we suspect that additional areas of suitable habitat are present along the west slope and bajada of the Sheep Range. We plan further fieldwork to circumscribe the range of this apparently rare species. At least until more populations are located, $P$. pygmaeum should be considered rare, with at least the type population possibly threatened by its proximity to a road, though the threat is probably slight at present. We recommend further studies to determine whether official listing may be necessary.

Associated Species. At the type locality Porophyllum pygmaeum occurs with the following species (listed in approximate descending order of abundance): Atriplex confertifolia (Torrey \& Frémont) S. Watson, Eriogonum trichopes Torrey, Lycium shockleyi A. Gray, Ephedra nevadensis S. Watson, Krameria parvifolia Benth., Acamptopap- pus shockleyi A. Gray, Artemisia spinescens D. Eaton, Yucca brevifolia Engelm. in S. Watson, Menodora spinescens A. Gray, Oenothera caespitosa Nutt., Opuntia basilaris Engelm. \& J. Bigelow, Aristida purpurea Nutt., Astragalus mohavensis S. Watson, Amsonia tomentosa Torrey \& Frémont, Brickellia oblongifolia Nutt., Lepidium montanum Nutt., Salazaria mexicana Torrey, Oryzopsis hymenoides (Roemer \& Schultes) Ricker, Eriogonum inflatum Torrey \& Frémont, Thamnosma montana Torrey \& Frémont, Langloisia setosissima (Torrey \& A. Gray) E. Greene, and Blepharidachne kingii (S. Watson) Hackel. The label for Ackerman 30904 lists Coleogyne, Ceanothus, pinyon pine, and juniper as associated taxa.

\section{LEAF ANATOMY}

Methods. Field-collected leaves of P. pygmaeum were preserved in Farmer's fixative (3 ethanol: 1 acetic acid; v:v), embedded, stained, and sectioned using standard techniques. Dry leaves of $P$. pygmaeum, P. greggii, and P. triden- 


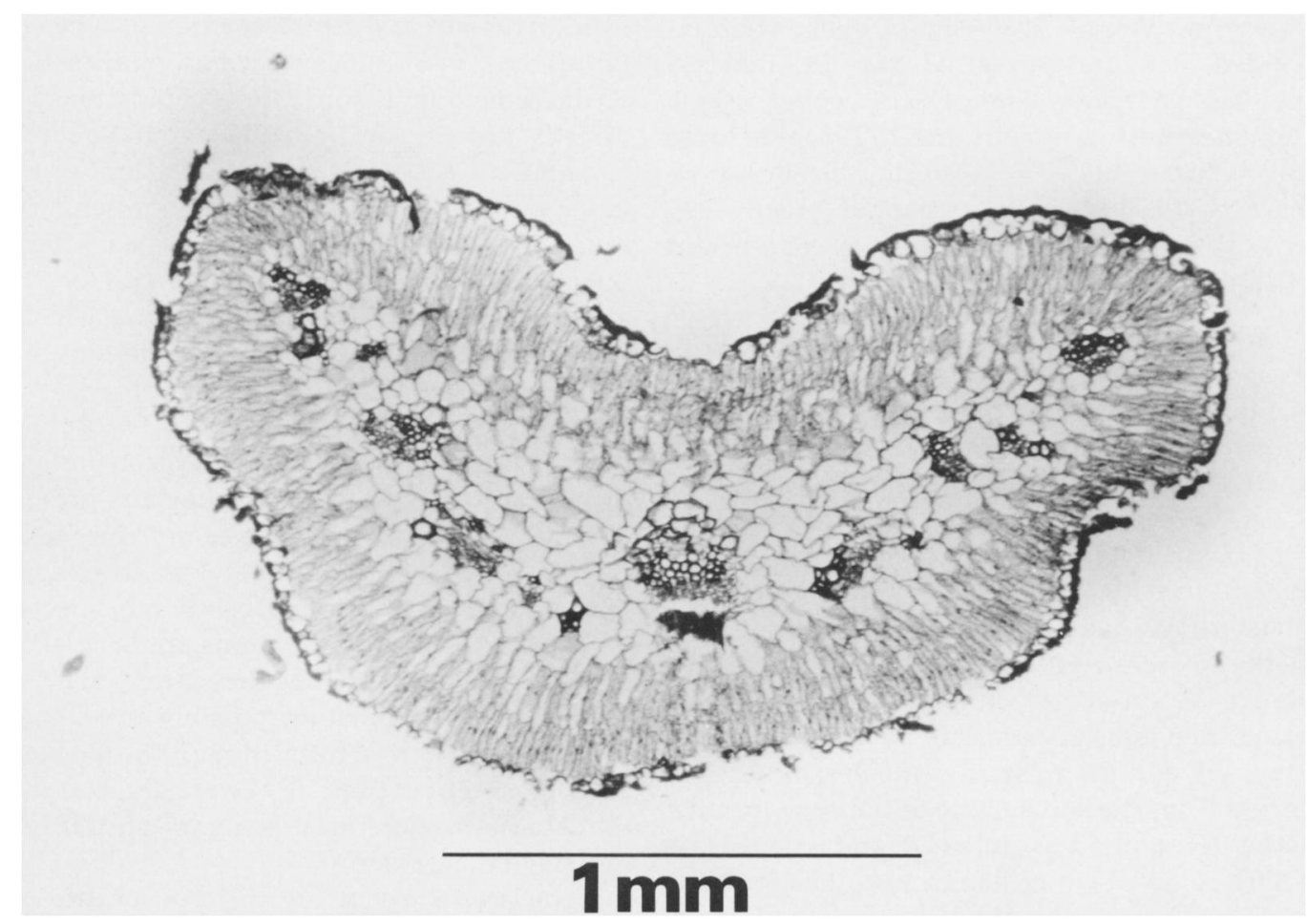

Fig. 2. Cross section of leaf of Porophyllum pygmaeum. This section does not include any foliar glands.

tatum var. crassifolium were rehydrated in a dilute aqueous detergent solution from herbarium specimens and hand-sectioned, and temporary mounts were stained with phloroglucinol.

Results. Except for distribution of foliar oil glands and the presence of an adaxial groove, the abaxial and adaxial portions of the subterete leaves of $P$. pygmaeum appear similar. The epidermis bears anomocytic stomata both ab- and adaxially. The cuticle varies from 19 to $30 \mu \mathrm{m}$ thick. A continuous double cylinder of palisade mesophyll surrounds a central zone of larger polyhedral parenchyma cells (fig. 2). Near the leaf base the abaxial layers of palisade mesophyll are absent. The outer cells of the central zone are typical isodiametric, chlorenchymatous spongy mesophyll with small air spaces at the cell "corners." The innermost cells of the central parenchyma zone lack both chloroplasts and air spaces, and are moderately elongated parallel to the veins. The midvein is centrally located within and smaller vascular bundles are scattered through the central parenchyma zone.
Two of the smaller veins are unbranched and parallel to the midvein. Occasional lateral veins diverge from the midvein at approximately a $20^{\circ}$ angle. At the leaf apex the midvein and main secondary veins converge into a vascularized mass with sclereids.

The foliar oil glands develop as nearly spherical lysigenous secretory cavities and are deeply invaginated into the palisade mesophyll and central parenchyma layers. Only the epidermis separates the glands from the abaxial leaf surface. The glands are hollow and are lined by several layers of flattened, presumably secretory cells. The glands do not bulge beyond the glandless portions of the leaf surface. A network of small veinlets surrounds each gland.

Leaves of $P$. greggii and $P$. tridentatum var. crassifolium appear internally similar to those of $P$. pygmaeum, although smaller in diam. Both are subterete with an adaxial groove and have a double cylinder of palisade mesophyll, a zone of spongy mesophyll, and an achlorophyllous central parenchyma region with embedded veins and veinlets. The central parenchyma zone 
is smaller in $P$. greggii and $P$. tridentatum var. crassifolium than it is in P. pygmaeum and appears to contain fewer veinlets. Foliar glands appear to be of similar structure and origin in all three species. Glands of $P$. tridentatum var. crassifolium differ somewhat from those of $P$. greggii and $P$. pygmaeum in that they often bulge beyond the leaf surface.

\section{RELATIONSHIPS}

Porophyllum pygmaeum is a member of sect. Hunteria as circumscribed by Johnson (1969). In Johnson's key it most closely approaches $P$. greggii and P. tridentatum. The former is an uncommon species of Trans-Pecos Texas. Porophyllum greggii, like P. pygmaeum, is a perennial herb. Both species have a chromosome base number of $x=12$; P. greggii is a hexaploid $(n=$ 36; Powell and Sikes 1970), and P. pygmaeum is a tetraploid $(n=24)$. Porophyllum greggii is often taller than $P$. pygmaeum $(10-30 \mathrm{~cm}$ vs. $5-15 \mathrm{~cm})$ and has a more sparsely leafy stem (internodes mostly $8 \mathrm{~mm}$ or more vs. mostly $3-7 \mathrm{~mm}$ ). The leaves of $P$. greggii are subterete, but are much longer (3-8 cm long) and somewhat more slender (ca. $1 \mathrm{~mm}$ in diam. when dry) than those of P. pygmaeum (1-1.5 cm long, $1.5-2 \mathrm{~mm}$ or more in diam.) and have 5-10 pairs of submarginal glands (3-5 pairs in P. pygmaeum). Internally the leaves of the two species are similar. Peduncles of $P$. greggii vary from 1 to $5 \mathrm{~cm}$, whereas those of $P$. pygmaeum range from 0.5 to $1.5 \mathrm{~cm}$. In size and form the heads and florets of the two species are similar (table 1 ).

Although the ranges of $P$. pygmaeum and $P$. greggii are separated geographically by about $1300 \mathrm{~km}$, their habitats are probably somewhat similar. Both occur in arid regions (P. pygmaeum in the Mojave Desert; $P$. greggii in the Chihuahuan Desert) with calcareous soils ( $P$. greggii also occurs on soils derived from igneous parent material) at similar elevations (1067-1981 $\mathrm{m}$ for $P$. greggii; $1355-2073 \mathrm{~m}$ for $P$. pygmaeum). Both species are exposed to freezing weather in winter. Associated species are not listed on the herbarium labels of any of the specimens of $P$. greggii that we have examined, but several species that occur at the type locality of $P$. pygmaeum are also present in deserts of Trans-Pecos Texas (e.g., Atriplex confertifolia, Aristida purpurea, Salazaria mexicana), and other genera are represented in the two areas by closely related species.
TABLE 1. Comparison of dimensions and numbers of reproductive structures of Porophyllum pygmaeum, $P$. greggii, and P. tridentatum vars. tridentatum and cras sifolium. Measurements are in $\mathrm{mm} .{ }^{\mathrm{a}}$ Heads were observed that probably contain more than 50 florets but these were not dissected.

\begin{tabular}{|c|c|c|c|c|}
\hline \multirow[b]{2}{*}{ Character } & \multirow[b]{2}{*}{$\begin{array}{c}P . \\
\text { pgymaeum }\end{array}$} & \multirow[b]{2}{*}{$\begin{array}{c}P . \\
\text { greggil }\end{array}$} & \multicolumn{2}{|c|}{ P. tridentatum } \\
\hline & & & $\begin{array}{c}\text { var. } \\
\text { tridentatum }\end{array}$ & $\begin{array}{c}\text { var. } \\
\text { crassifolium }\end{array}$ \\
\hline Phyllary length & $8-11$ & $8-14$ & $7-10$ & $6-8$ \\
\hline Phyllary width & $2-4$ & $2.5-4.5$ & $1.5-4$ & $2.5-4$ \\
\hline Number of florets & $25-75$ & $25-50^{a}$ & $25-40$ & $25-40$ \\
\hline Corolla length & $7-8$ & $8-9$ & $5-6$ & $6-7$ \\
\hline Pappus length & $6-7$ & $9-10$ & $5-6.5$ & $5-6$ \\
\hline Achene length & $7-8$ & $5.5-8.5$ & $3-3.5$ & $2.5-3$ \\
\hline
\end{tabular}

Porophyllum pygmaeum resembles $P$. tridentatum of Baja California in having short, thick, subterete leaves that are crowded on the stem. Porophyllum tridentatum was treated by Johnson as comprising var. tridentatum, with tridentate leaves and var. crassifolium with entire leaves. These taxa were maintained as separate species by Wiggins (1964, 1980). Both have a chromosome number of $n=15$ (Johnson 1969; Reveal and Moran 1977) in contrast to the $n=24$ of $P$. pygmaeum. Porophyllum pygmaeum differs from varieties of $P$. tridentatum by its herbaceous rather than suffruticose habit and by details of leaves and reproductive parts. Leaves of $P$. pygmaeum are subterete with an adaxial groove (figs. 1B, $C, 2$ ) and bear a pair of subterminal oil glands and 3-5 pairs of submarginal glands $0.3-0.7 \mathrm{~mm}$ in diam. or length. Leaves of $P$. tridentatum are internally similar to those of $P$. pygmaeum but have a smaller central parenchyma zone. Those of var. tridentatum are cuneate with three (or occasionally more) apiculate-tipped teeth or lobes, each bearing a swollen oil gland; leaves of var. crassifolium are entire with a single subterminal gland. The diameter of the subterminal gland(s) of P. tridentatum leaves is proportionally greater than that of the corresponding glands of $P$. pygmaeum and sometimes exceeds the diam. of the green portion of the leaf. In $P$. tridentatum var. crassifolium the number of submarginal glands seldom exceeds one or two pairs. The various reproductive parts of $P$. pygmaeum tend to be larger than those of $P$. tridentatum, although extreme measurements for some characters overlap (table 1). The most readily 
apparent difference is achene length; achenes of $P$. pygmaeum average two or more times as long as those of $P$. tridentatum.

Habitats of $P$. pygmaeum and P. tridentatum appear to have less in common than those of $P$. pygmaeum and P. greggii. Porophyllum tridentatum occurs in lowland, hot desert habitats along the eastern coast of Baja California and on adjacent islands. Freezing weather seldom or never occurs in these habitats.

Porophyllum gracile Benth. is the only other member of the genus known to occur in $\mathrm{Ne}-$ vada, California, and northern Arizona. It reaches its northern limits in Clark and Esmeralda cos., Nevada. It is a slender broom-like subshrub $20-60 \mathrm{~cm}$ tall with thin, linear, bifacial leaves to $5 \mathrm{~cm}$ or more in length, narrowly cylindrical heads with 5-30 florets, and white to greenish or pale purple corollas. Both species have strongly scented herbage, but the odor of $P$. gracile is strikingly different from that of $P$. pygmaeum. Although $P$. gracile is also a member of sect. Hunteria, it is probably only distantly related to $P$. pygmaeum. No plants of $P$. gracile were observed at or near the type locality of $P$. pygmaeum. Johnson (1969) indicated that P. gracile occurs in the coldest areas occupied by any species of Porophyllum. It now shares that distinction with P. pygmaeum.
ACKNOWLEDGMENTS. JDM expresses appreciation for the excellent company and assistance of Friedrich Ehrendorfer, Aaron Liston, and Sara Meury in the field, and DJK acknowledges the able fieldwork and companionship of Lawrence Kelly. Lawrence Balthaser determined the rock samples gathered from the type locality. Sherwin Carlquist assisted with the anatomical studies. The line drawings were prepared by Joanna Tomassacci. We thank A. Michael Powell for making specimens of $P$. greggii available on loan from SRSC, and Rhonda Riggins, John Strother, and Arnold Tiehm for reviewing our manuscript and for their helpful comments.

\section{LITERATURE CITED}

JoHNSON, R. R. 1969. Monograph of the plant genus Porophyllum (Compositae: Helenieae). Univ. Kansas Sci. Bull. 48:225-267.

POWELL, A. M. and S. SIKES. 1970. Chromosome numbers of some Chihuahuan Desert Compositae. Southw. Naturalist 15:175-186.

Reveal, J. L. and R. Moran. 1977. Miscellaneous chromosome counts of western American plantsIV. Madroño 24:227-235.

Wiggins, I. L. 1964. Part II. Flora of the Sonoran Desert. Pp. 189-1740 in Vegetation and flora of the Sonoran Desert, eds. F. Shreve and I. L. Wiggins. Stanford, California: Stanford Univ. Press. . 1980. Flora of Baja California. Stanford: Stanford Univ. Press. 